\author{
ZVEZDAN M. ARSIĆ ${ }^{1}$ \\ UNIVERSITY OF PRIŠTINA IN KOSOVSKA MITROVICA \\ Faculty of Philosophy, Department of Pedagogy \\ JeLENA B. BABIĆ ANTIĆ ${ }^{2}$ \\ UNIVERSITY OF PRIŠTINA IN KosovSKA MITROVICA \\ FACULTY OF PHILOSOPHY \\ DEPARTMENT OF ENGLISH LANGUAGE AND LITERATURE \\ TATJANA S. RADOJEVIĆ ${ }^{3}$ \\ UNIVERSITY OF PRIŠTINA IN KOSOVSKA MITROVICA \\ Faculty of Philosophy, Department of PeDAgogy
}

\title{
STUDENT'S STATUS IN CONTEMPORARY TEACHING: PROBLEMS AND PERSPECTIVES
}

\begin{abstract}
It is widely known that teaching as a social and historical category, during various periods of civilizational development, was characterized by several direct and specific factors, with the pupil (student) as a specific category. The status of the student in the process of teaching has been changing during the historical development of the society, which resulted in the change of their role. During the teaching process, the student is preparing for various roles in the society. Therefore, teaching should be in the function of accommodating conditions and enabling the student to participate in decision-making, to develop skills and habits, as well as to develop the ability for learning, thinking, remembering, problem solving, and intellectual independence, as well as the ability to use the gained knowledge in practice. Due to all the previously mentioned, main attention of this paper will be
\end{abstract}

\footnotetext{
zvezdanars@gmail.com

jbabicantic@gmail.com

tatjana.radojevic@yahoo.com
}

This paper is the result of the research conducted within the project III 47023 Kosovo and Metohija between national identity and European integration, funded by the Ministry of Education, Science and Technological Development of the Republic of Serbia.

This paper was submitted on August $20^{\text {th }}, 2019$ and accepted for publication at the meeting of the Editorial Board held on September $16^{\text {th }}, 2019$. 
focused on comparative-critical and descriptive analysis of a student's status and role in the historical development of teaching, with particular attention on the condition and problems in contemporary teaching.

KEYWORDS: teaching; student; teacher; students' status; students' role.

INTRODUCTION

The longest, the most beautiful, and the most turbulent part of their lives, children and youngsters spend as pupils in school and similar educational institutions. In those institutions, they learn, develop habits and abilities, develop the scientific view of the world, as well as prepare how to proceed with their further education and gain experience to perform various vocations. A high degree of agreement exists among most of the people involved in any kind of educational work that the school is a community which supports the development of psychophysical, socio-cultural potentials, as well as development of abilities, which will enable the use of acquired knowledge in practical work. Similarly, a high degree of consensus exists regarding the contemporary teaching and its main task, which should be the exclusion of traditional approach and development of the conditions in which the students will be responsible for their own learning.

The entire XX century, especially its second half, and the beginning of the XXI century are characterized by reformist ideas aiming to create the ideal concept of education. The conditions of the "old school"-with the student as the passive receiver and the re-producer of the learning content, obliged to carefully listen to the words of the teacher and memorize and reproduce them as precisely as possible-have been widely and justifiably criticized by pedagogues and experts from various scientific fields. Nevertheless, even with the "new school" offering qualitatively new theoretical and practical solutions for the position and role of the student in the teaching process, the question is what has changed and how have those changes affected the position of the student; or if there is still the discrepancy between contemporary pedagogical theory and the teaching practice. This is the main shift in the student's status and it is influenced by various subjective and objective factors. The modern age has brought certain changes, which inevitably affect the teaching process. That is why it has to be prepared to 
face the challenges of the modern era and to create the necessary conditions for the transformation of student's status. The result should be the acceptance of students as equal partners, both as active and genuine subjects in the process.

\section{STUDENT'S STATUS IN TEACHING DURING THE HISTORICAL DEVELOPMENT OF SOCIETY}

The process of teaching is a social and historical category and is shaped by various direct and indirect factors. The student is considered the most important direct factor. They happen to be the most important raison d'etre of the whole school system and the teaching practice (Ковачевић, 2017, p. 640). Throughout the historical development of the society and school, the pedagogical view of the student in the teaching process was always present. Hence, it is necessary to point to some evolutional characteristics of the pedagogical position of the student throughout the history of school development. In the beginning of the school history, in countries of the Ancient East (India, China, Babylon, and Egypt), the aim of the education was to provide the sufficient number of literate people. This was the crucial aspect of the existence and the development of the society. The process of teaching was mainly directed towards gaining basic literacy-reading, writing, and knowledge of the law. Later, during the Antiquity era, the aim of education was directly conditioned by the needs of the slaveholding society, significantly differing from country to country. The best way to learn about it is by reading about the ways of teaching in Sparta, Athens, and Rome. The education in Sparta was subjected to military discipline and the youth in school were taught to be obedient in executing the tasks, to be brave, persistent, harsh, and cunning in battle. There was no room for their free development. They were also severely punished for any kind of disobedience. Meanwhile in Athens, the focus was on the harmonious development of the student, with significant attention put on cognitive, moral, and physical education. First schools in Rome practiced a very rigid discipline with frequent and severe physical punishments. Their students learned by heart. Later, with the appearance of M. F. Qantilian (Marcus Fabius Quintilianus, 35-96 AD), students exercised their oratory skills, due to the existing belief that only good orators could appease the 
internal mutinies and disputes. In addition to that, the students in Rome were taught to be good warriors, since the Rome was a military state, the education had a military character as well.

What characterizes the schools of ancient eastern civilizations and the classical period is the fact that the student was in a subordinate position, blindly obedient. The adjustment of their personality was in accordance with the interests and needs of the slaveholders' class. Somewhat better position was that of a student in Athens, where general education was combined with the military education. It purported the knowledge of philosophy, politics, science, art, and law. The student also had the right to choose a teacher. The fact is that there was subdual, hard work, careful listening, learning without significant psychological activity, bodily punishment, blind respect for teacher's authority, education for the purpose of a particular class, and a lack of opportunities to form the scientific view of the world. This leads to the conclusion that, in the times and schools mentioned above, the students were treated as objects.

When the Roman Empire collapsed in $476 \mathrm{AD}$, so did the slaveholding society and the new feudal system was formed. The complete authority in the state was taken over by the church, which also had a monopoly over most of the aspects of life and work, and accordingly over science and education, as well. The science was considered a "theology's handmaid" and the education had a religious character. Priests were assigned to be the teachers and they were preaching the unconditional obedience, sufferance, moderation, work, and asceticism. The aim of teaching was to instil obedience and loyalty toward God's will (Ковачевић, 2017, p. 646). According to the nature of the education, first schools in the feudal society were clerical (in monasteries, cathedrals, and parishes) and students were trained to become clergymen. Lecturing was based on mechanical learning of church books which were firstly copied by the students, then used to study from them in Latin. Reading, writing, and Latin presented the base for a teaching programme in clerical schools. Passive methods of teaching were used in the process, learning lacked understanding (involving only what was necessary for doing the work), and the role of the teacher was a dominant one. This kind of organization of the teaching process characterized by students' servitude to the pedagogical authority of the church doctrine created conditions for the development of perception by which the position of the student was the least con- 
venient during the feudalism, when compared to the very beginning of teaching and tuition.

The further development of the society brought along the creation of new ideas for the organisation of teaching. The aim was to aspire toward reconciliation between reason and religion, the adjustment of faith and science (scholastics), and formation of a new view, which would place the human into the centre of attention, together with the spectre of changes and restorationsHumanism and Renaissance. This approach created conditions for the development of the view by which the student would be the most important factor, their personality would be respected, and their natural course of development appreciated. In regards to that, the church monopoly over education and tuition was harshly criticized. Furthermore, corporal punishment and the student role and position in the teaching process was frowned upon. Special attention was awarded to intellectual education. Mere mechanical learning was criticized and the focus was placed on the importance of student's activity in the process of acquiring knowledge. One of the most well-known pedagogues and humanists, Michel Montaigre (Michel de Montaigre, 1533-1592), believed that "[...] it is necessary to notice not by mere listening, but by acting upon, in order for the knowledge to become an internal achievement" (Montaigre, 1953, p. 54). The representative of the utopian socialism, Thomas More (Thomas More, 1477-1535), insisted on the knowledge which would be practically applicable and which should arise from the conscious involvement of the student. Likewise, the founder of materialistic philosophy, Francis Bacon (Francis Bacon, 1561-1626), did the same.

Humanism and Renaissance, and especially the appearance of the new bourgeois society with a whole "pleiad" of pedagogical and didactical theoreticians and practitioners, created conditions for a new attitude toward the position and the role of a student in the teaching process. This issue was considered by all the classical thinkers of pedagogy-Joanes Amos Komenius (1592-1670), John Locke (1632-1704), Jean-Jacques Rousseau (1712-1778), Johann Heinrich Pestalozzi (1746-1827), Johann Friedrich Herbart (1776-1841), Friedrich Wilhelm August Fröbel (1782-1852), Friedrich Adolph Wilhelm Diesterweg (1790-1866), John Dewey (1859-1952), Georg Kerschensteiner (1854-1932), K. D. Ushinsky (Константин Дмитриевич Ушинский, 1824-1871), A .S. Makarenko (Антон Семёнович Макаренко, 1888-1939), N. K. Krupskaya 
(Наде́жда Константи́новна Кру́пская, 1869-1939), Edward Lee Thorndike (1874-1949). The core of their views lies in the criticism of the "old school". It was characterized by the status of the student as an object, their subordinate position in the teaching process, insufficient activity (mechanical learning and reproducing the learned), rigid organization of teaching, physical punishments, and belittlement of the students. Their views contributed to the appearance of new ideas in the history of pedagogy. The favourable pedagogical climate for the change of the student's status was created. Since then, students gained a more active status, appreciation of their personality, adjustment of the teaching process according to their natural abilities, opportunity to learn by involving one's intellectual activity, and developing logical thinking.

\section{STUDENT'S STATUS IN CONTEMPORARY TEACHING}

The authors who closely dealt with the position of the student in the school system (Šimleša, 1970; Poljak, 1972; Malić, 1972; Prodanović \& Ničković, 1974; Bandjur, 1984; Bandjur, 1985; Lavrnja1985; Havelka 1999; Havelka, 2000; Мијановић, 2008; Tot, 2010; Ковачевић, 2017) consider the medieval, authoritative, etatist school-which was dominated by the so called "repressive pedagogy" with repressive ways of upbringing, based on old authority, rigid requests, iron discipline, and ruthless punishments-as diametrically opposite to the modern educational system. For example, after the statement that the grounds of the "old school" and its teaching methods were significantly moved by the intensive development of natural sciences, with some "painful punches" given by the studies in child and differential psychology, V. Bandjur (1984, pp. 465-469) discussed Rousseau's pedagogical naturalism based on natural development of a child; Dewey's pedagogical subjectivism, which apostrophized the experience of the student; Kerschensteiner's working-school, whose essence was to use the least material for memorizing and gain the maximum skills, abilities, and working joy; Adolph Ferier's active school promoting the educational process of children's well-being based on biology; and experimental pedagogy as opposed to the "old school" with the experiment, systemic observation, statistical techniques, and mathematical models like those from the natural sciences. 
In addition to directions affirming the subjective position of the students, V. Bandjur (1984, pp. 471-479) also spoke of teaching systems which resulted from the radical critique of the "old school" and the class system, particularly by referring to the following systems of teaching:

- the teaching system of J. O. Decorly based on students' affinities;

- Jenaplan schools of P. Petersen, where elementary groups were introduced instead of classes and subjects were replaced by free conversations on life-important problems;

- Project Method of V. H. Kilpatrick with the maximum respect for instinct-based affinities and natural spontaneous activity of the students;

- Mannheim system of J. Sickinger, who found a solution in sorting students according to the degree of their mental development;

- Dalton Plan by H. Parkhurst, who believes that students should be approached not only individually, but also in an individualized manner;

- Winnetka Plan by K. Woshbern aiming to reconcile and bring into connection the individualized and group forms of teaching;

- laboratory brigade system of teaching characterized by the individual work of groups (brigade) after receiving the tasks and other necessary instructions;

- the custom-made school of E. Clapperds, which completely respects the student and which is based on their needs, abilities, opportunities, and development potentials;

- the system of M. Montessori, which started with the child and the biological determinism, suggesting that a child should be given the adequate environment and adequate tools (didactical materials) and with their help the child will be able to freely and individually express its biologically given activity; and

- free group work according to R. Kuzin with elements introduced into the environment in accordance with the child's wish.

Unlike the approach of V. Bandjur, who sees the historical turn in the student's position in pedagogical orientations and bourgeois reformist movements, N. Havelka (1999, pp. 20-29) speaks of educa- 
tional concepts and their impact on students' status in the teaching process. Accordingly, he states that:

- cognitive or academic concepts promote the involvement and development of student's cognitive capacities;

- personalized or humanistic concepts develop the emotional aspect of student's experience and behaviour in school, particularly observing the communication with the teacher and other students;

- behaviouristic or technological concepts focus on school or teaching situations, as well as the exact environment designed to provoke certain ways of behaviour;

- interactional or socio-activist concepts aim to bring the students into interpersonal groups and active patterns of behaviour, where the basis for education lies in the communication between the teacher and the student; and

- combined model insists on development in the form of prepared solutions which should be able to present the basis for the educational work in school.

Each of the previously mentioned concepts could be oriented in an exclusive direction (clearly differing from other concepts and insisting on originality of one's own ideas, concepts, and arguments) and inclusive (looking up to other concepts, their values considered valid and reliable).

Unlike the stereotypical teaching, which presents the synonym for "old school", we consider the modern type of teaching to be a specifically organized and institutionalized process of gaining knowledge, skills, and habits, with simultaneous involvement of communication and interaction between students and teachers, according to previously defined and verified teaching plan and program (Мијановић, 2008, p. 14). However, while analysing the development of school and teaching during the historical development of the society, V. Poljak (1972, p. 105) believes that even then, in the "old school" environment with repressive education, there was a seed of a new view. According to the law of dialectical development, that seed had a significant evolution, with various and expectable oscillations, depending on conditions of the society. This attitude points to a conclusion that after all, the "old school" should be taken as a standing point when analysing and elaborating on the student's status in modern teaching. This should be done mainly because three concepts were identified during its historical 
development: student as an object, student as the subject, and student as an object and the subject. Each of the three concepts had characteristic normative, theoretical, and organizational solutions.

\section{CHARACTERISTIC PROBLEMS RELATING TO UNDERSTANDING OF STUDENT'S STATUS IN CONTEMPORARY TEACHING}

The "old school" critique consequently brought about the rejection of didactic concepts of "teaching knowledge" and a new didactic concept of "earning knowledge" was introduced (Poljak, 1972, p. 106). This new, contemporary school and teaching have also rejected the teacher as authoritative and dominant in relation to students. A significant turn occurred when a new concept of the teacher as student representative in the society was introduced. The student (pupil, attendee, and alike) is a person who receives knowledge, develops skills and habits, creativity and other abilities, strengthens and confirms their personality, in a didactically and educationally based teaching process. (Branković \& Ilić, 2011, p. 111). Therefore, the aims and curricula of the "new school" are chosen according to the students' needs. This new relation on a certain level of development of pedagogics and teaching, meant the absolutisation of student's pedagogical status. Consequently, conditions were created for the development of "pedo-centrism" and the status of the student as the active subject. This explicit request for subjective position purports that the student sets the goals, chooses the curricula, studies individually and is not being taught, but independently evaluates the educational accomplishments (Мијановић, 2008, pp. 14-15). It is of great importance to take care not to accept the pedo-centric view of student's subjectivity, by which they are placed above the teacher and teaching, instead of being in the middle of the teaching process. That would lead the students to themselves, to their own enclosure, final individualism, and further to excessive liberalism, anarchism, intolerance, and dehumanization of personality. From the point of view of contemporary pedagogy, that is entirely unacceptable.

All discussions about the school reform and new contemporary teaching, which would ensure the realization of educational tasks in the most efficient way, ask the question of how to make sure the 
student have a status of the subject in the process and still preserve the logical and didactical structure of the teaching process, as well as the role of a teacher in it. The biggest change affecting the modern school is the awareness that teacher's role is changed. This altered the organization and execution of teaching. Nevertheless, the modified relationship between the teacher and the student cannot be observed in isolation from all the changes that characterize the modern society. Consequently, we can conclude that all the requests for the subjective status of the student in the process of their own development, present a mark of fundamental change in the society, originating from its development. These changes in school organization had a significant influence on teachers. They are no longer the managers of educational work, the main contributors to the teaching process, including the student's development. From now on, they become leaders, advisers, those who control, support, and learn how the student will learn (Malić, 1972, pp. 133-134). In the modern school, the student is treated as someone whom the teacher will enable to construct knowledge, develop abilities. Furthermore, the teacher educates and influences the formation of certain values. With exquisite skills to organize, carry out, and boost the teaching process, the teacher joins the mix of other teaching factors, their effect depending on the preparedness, especially on their inter-factor correlation (Prodanović \& Ničković, 1974, p. 115).

Various studies of student's status as the subject in the teaching process mention different concepts-student's activity, student's self-responsibility, partnership between the teacher and the student, student's self-development, cooperation between the two as equal partners, and alike. If we would try to define the notion of a subject from a pedagogical viewpoint, then we would be able to say that the subject is an agent of the educational process. Assuming that the student is the subject brings us to the conclusion that they are also the owner of the educational process. In order to avoid misunderstanding, due to this absolutistic view of the student's status in the modern school, it is vital to mention that teachers are subjects as well and agents of the educational process, only with a different pedagogical function. It would be very dangerous and harmful for the teaching process to underestimate, reduce, or even exclude the pedagogical function of the teacher.

Previously elaborated views all point to the conclusion that individual and common roles of students and teachers in the organiza- 
tion and realization of the teaching process are determined by numerous objective and subjective factors. The group of objective factors includes scientific and technological, economic, cultural, and social development, accomplishments in certain social communities, in a particular period of time. Accordingly, this group of factors purports the knowledge of normative and legislative regulations that are used to determine social and educational relations (school system, legal system, socially determined aims and educational tasks, teaching curricula, material, and technological infrastructure). When it comes to subjective factors, it is a matter of expert, didactical, and methodological qualification of the teacher, as well as the structure of their intellectual, character, emotional, and motivational traits. In addition, subjective factors which determine the status of the student are also cognitive, emotional, and psycho-physical characteristics. They define the structure of each person individually, the structure of the class, social environment and social status, educational degree and professional activity of the parents, as well as the formation of the attitude toward the school and the teacher.

\section{PERSPECTIVE OF STUDENTS' STATUS IN CONTEMPORARY TEACHING}

A shift in social relations, different function of the school, science, technology, and civilizational development significantly contributed to the change of student's role and status in the teaching process. However, the results of numerous studies of the teaching practice show that this shift is neither easy, nor fast. It is also evident that there is still a gap between modern pedagogical theory and the teaching practice. Accordingly, a logical and justified question is what the cause of such a state seems to be. Authors who deal with the analysis of our teaching practice (Мијановић, 2008; Vilotijević, 2000; Havelka, 2000; Прушевић-Садовић, 2016; Зукорлић \& Поповић, 2017), find the reasons for such a state in both students and teachers, as well as subjective and objective factors which determine their relationship. It has been established that students are "overladen" with learning material, without sufficient motivation to participate in the realization of the teaching process, and with significant lack of critical thinking skills. Besides, due to indi- 
vidual differences between the students, their activity varies depending on the class subject, content of the course, dominant form and method of teaching, age and prior knowledge, type of school, working style, and teachers' behaviour. If the student only listens and tries to memorize information received from the teacher, without trying to analyse and apply it, to draw conclusions and generalize; if the student is not interested and does not experience the cognitive conflict and dissonance; if they do not ask questions, try to find the answers display curiosity, then they cannot have the subjective status in the process of teaching. In that case, students can only be a mere object and a passive participant in the process (Младеновић, 2006, p. 125). When it comes to teachers, the most common obstacle is their inadequate preparedness for more complex and more responsible roles, insufficient motivation, poor social status, and exceedingly large number of classes and other obligations prescribed by the curriculum. In addition, the teachers are not free to choose the lesson materials since they are bound by the curriculum. Hence, teachers' autonomy should be examined in the context of curricula, according to which they are supposed to be active, have the freedom of choice and decision making, but also be accountable for the choices and decisions they make, and the due consequences. Regardless of the fact that both previous and current normative and legislative acts (Закон о основама система образовања и васпитања, 2009; 2013; 2017) allegedly place the student in the centre of the educational process, that goal seems impossible to accomplish due to human resource issues, material, technical, and social conditions. Therefore, the essence of the problem lies in the fact that there are differences which have existed throughout the whole historical development of school and teaching, which still do exist, between the goals proclaimed by the society and those actually achieved.

Striving to create conditions for overcoming the current state, various ideas and suggestions for solutions have emerged. Recognizing the fact that the subject position of the student in the educational process presupposes their active individual participation in teaching and extracurricular activities and responsibility for their own development, one of the possible solutions is the individualization of teaching using modern educational technology, starting from the planning phase, through the selection of educational content, courses, forms of work, methods, procedures, and approaches to evaluation. By using the modern technologies in the planning 
phase, a significantly more active role of the student is achieved. Likewise, the teacher is in the position to lay out and present the global curriculum and subject plan by using various methods. Different interests and opportunities for students to use various modern educational technologies can be achieved while designing the curricula, subjects, procedures, forms, and work methods; by using the multi-media materials and actively participating, students are able to overcome the subject problems with more efficiency; they are highly motivated for thinking, logical analysis, and drawing conclusions. In addition, students are able to deal with certain units of the syllabus on their own, either guided or controlled by the teacher. The usage of modern educational technology makes the process of evaluation easier, it becomes more objective and efficient. By using computers and other digital devices, students can have their individual work assessed, can get answers and feedback on the quality of their work, etc. Hence, students have the opportunity to continuously monitor their own work, which presents the best way for permanent and constant self-evaluation.

Modern educational technology and multi-media tools do not present an a priori guarantee for successful overcoming of the problems. Still, if they are adequately used and if there are certain conditions for their use (material and technical resources), devices and means of modern informational technology can present a significant asset in creating the proper environment for the students. Multi-media and digital environment, which characterize the life of young generations, have become their natural habitat which enables them to easily find their way in the world of virtual communication, faster flow of information, with more curiosity and activity. Nevertheless, even though the modern means of educational and informational technology are highly welcome and present a significant asset for the student in the process of learning, they cannot replace the role of a teacher. Teacher's prerogative, which makes them the irreplaceable factor in the teaching process, remains their didactical and methodological expertise. Their knowledge of pedagogical and psychological principles and rules presents a crucial help to students on their way to knowledge and maturity (Прушевић-Садовић, 2016, p. 104). Development of science, engineering, and technology will continue to bring about the rapid changes in education, but they will not be able to educate personalities. Therefore, when seeking for the right conditions which could enable the total accomplishment of student's subjec- 
tive status, it would be wise to start from establishing different, more humane, more equal and first of all, more direct relations between students and teachers. Among numerous problems which are evident in the modern school, one of the most obvious is the relationship between the participants in the teaching process. The subjective status of the student in the process of teaching demands for both parties to understand each other, respect the partnership and collaboration, with clearly set tasks, rights, and obligations for each of the two. Building a proper relationship between the student and the teacher is a fundamental issue in contemporary school and teaching; insisting on this partnership is a natural part of educational work which significantly differs from all other social activities. Surely, striving to create the pedagogical climate as favourable as possible, which could enable the student to reach the more active and equal status, is necessary to establish a significantly higher degree of democracy in the society. The main prerequisite for accomplishing this goal is for the student to be active and genuine subject in the contemporary teaching process.

CONCLUSION The status and role of the student in the teaching process were treated differently throughout the certain stages of societal development. By following the school development and the system of education at various levels of civilizational development, it is possible to conclude that students mainly had the passive, submissive, and very often, a humiliating status. In certain shorter periods of history, particularly in the era of Humanism and Renaissance, the period of edification, as well as during the influences of pedagogical ideas and movements of the bourgeois society, the status of the student was somewhat better. However, the fact remains that their inferior position did not significantly change since the constitution of the class system in the school until the last quarter of the previous century. Insufficient development of pedagogical theory and the teaching practice significantly contributed to such a state of affairs. Surely, that kind of schooling and teaching („old school“) were ruthlessly criticized. That relationship generated numerous new ideas soon to become pedagogical movements, approaches, and systems, supporting free development of the student and gaining knowledge as consequential effects of their own observation and thinking; students' activities and functional knowledge presented their imperative requests. Some of the efforts led astray. Attempting to find the answer to the unbearable passive status of 
the student in teaching, in a particular stage of the development of pedagogics, led to the-so-called "pedo-centrism". Pedo-centrism followed a course which considered the student as the active subject. Altered social relations, different school function, and development of science, technology and civilization in general have significantly contributed to the change of the student's status in the process of teaching. Major change that happened during the societal development and progress of the teaching system, as well as the status of the students in it, resulted mainly from the change of the teacher's role. Since then, the teacher stopped being the agent of the educational work, manager of all the actions involving student's development; from then on, they became leaders, advisers, those who control, support, and learn how the student will learn. Nevertheless, there are numerous problems caused by objective and subjective factors, such as the changed role of the teacher and the status of the student as the subject, their mutual relations of respect and clearly provisioned tasks, rights, and obligations. Striving to achieve this can contribute to overcoming problems, creating conditions for affirmations and achieving the subjective role of the student in modern teaching. Surely, it would be necessary to create an adequate pedagogical climate and social environment in order to achieve these goals.

REFERENCES Вилотијевић, М. (2000). Дияакӣuка. Београд: Завод за уџбенике и наставна средства - Учитељски факултет.

Закон о основама систетема образовања и васииийања (2009). „Службени гласник Републике Србије“, бр. 72/09.

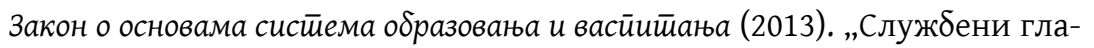
сник Републике Србије“, бр. 55/2013.

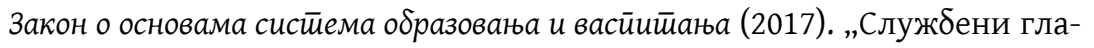
сник Републике Србије“, бр. 88/2017.

Зукорлић, М. и Поповић, Д. (2017). Повезаност школске климе и аутономија ученика. Иновације у наст̄ави, XXX (3), 99-1008.

Ковачевић, В. (2017). Положај и улога ученика унастави крозисторијске епохе. Учење и насйава, III (4), 639-654.

Мијановић, Н. (2008). Субјекатска позиција ученика у васпитно-образовном процесу између декларативног и стварног. Иновације у насйави, 21 (1), (13-22). 
Младеновић, У. (2006). Субјекатска позиција ученика и његово дожи-

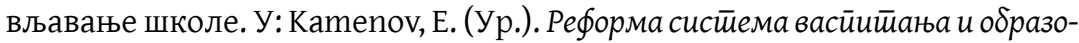
вањ у Рейублиции Србији (119-129). Нови Сад: Филозофски факултет.

Banđur, V. (1984). Mjesto i uloga učenika u nastavi nove škole. Pedagogija, XXII (4), (465-483). Beograd: Savez pedagoških društava Jugoslavije.

Прушевић-Садовић, Ф. (2016). Неопходност проширења трофакторског система наставе у вишефакторски. Иноващије у насйави, XXIX (3), 100107.

Хавелка, Н. (2000). Ученик и насӣавник у образовном ӣроцесу. Београд: Завод за уџбенике и наставна средства.

Banđur, V. (1985). Učenik u nastavnom procesu. Sarajevo: „Veselin Masleša“.

Branković, D. \& Ilić, M. (2011). Uvod u pedagogiju i didaktiku. Banja Luka: Comes-grafika.

Havelka, N. (1999). Koncepcije obrazovanja i položaj učenika u nastvanom procesu. Pedagogija, XXXVII (3), 19-33.

Lavrnja, I. (1985). Učenik kao subject obrazovanja. Rijeka: Izdavački centar.

Malić, J. (1972). Uloga nastavnika u formiranju učenika kao subjekta. Pedagoški rad, XXVII (3-4), (133-142).

Montenj, M. (1953). Ogledi o vaspitanju. Beograd: Pedagoško društvo NRS.

Poljak, V. (1972). Učenik kao subject u školi samoupravnog društva. Pedagoški rad, XXVII (3-4), (103-119).

Prodanović, T. \& Ničković, R. (1974). Didaktika. Beograd: Zavod za udžbenike i nastavna sredstva.

Šimleša, P. (1970). Društvena osnova našeg shvaćanja aktivnosti. Zagreb: Pedagoško-književni zbor.

Tot. D. (2010). Učeničke kompetencije i suvremena nastava. Odgojne znanosti, $12(1), 65-78$. 


\author{
ЗВЕЗДАН М. АРСИЋ \\ УНИВЕРЗИТЕТ У ПРИШТИНИ СА ПРИВРЕМЕНИМ СЕДИШТЕМ \\ У КОСОВСКОЈ МИТРОВИЦИ, ФИЛОЗОФСКИ ФАКУЛТЕТ \\ КАТЕДРА ЗА ПЕДАГОГИЈУ \\ ЈЕЛЕНА Б. БАБИЋ АНТИЋ \\ УНИВЕРЗИТЕТ У ПРИШТИНИ СА ПРИВРЕМЕНИМ СЕДИШТЕМ \\ У КОСОВСКОЈ МИТРОВИЦИ, ФИЛОЗОФСКИ ФАКУЛТЕТ \\ КАТЕДРА ЗА ЕНГЛЕСКИ ЈЕЗИК И КЮИЖЕВНОСТ \\ ТАТЈАНА С. РАДОЈЕВИЋ \\ УНИВЕРЗИТЕТ У ПРИШТИНИ СА ПРИВРЕМЕНИМ СЕДИШТЕМ \\ У КОСОВСКОЈ МИТРОВИЦИ, ФИЛОЗОФСКИ ФАКУЛТЕТ \\ КАТЕДРА ЗА ПЕДАГОГИЈУ
}

РЕЗИМЕ

\title{
ПОЛОЖАЈ УЧЕНИКА У САВРЕМЕНОЈ НАСТАВИ - СТАњЕ, ПРОБЛЕМИ, ПЕРСПЕКТИВА
}

Опште је познато да је наставу као друштвено-историјску категорију током различитих периода цивилизацијског развоја карактерисало постојање више непосредних и посебних фактоpa, међу којима се посебно издвајао ученик. Положај ученика у наставном процесу се током историјског развоја друштва мењао, што је условљавало и промену његове улоге. Будући да се положајем у настави ученик припрема за различите улоге у друштву, она, од првог дана школовања, треба да буде у функцији стварања услова који ће му омогућити учествовање у доношењу одлука, формирању вештина и навика, развијању способности за учење, мишљењу, памћењу, разумевању, решавању проблема, интелектуалном осамостаљивању и примени стеченог знања у пракси. Међутим, и поред тога што међу ауторима који се ближе баве проблемом положаја и односа наставника и ученика постоји релативно висок степен сагласности о томе да се један од најважнијих задатака наставе огледа у спремности за напуштањем традиционалног приступа и створе услови у којима ће ученици бити одговорни за сопствено учење и што читав XX век, нарочито његову другу половину, као и почетак XXI века, карактеришу многе реформистичке идеје са циљем да се створи идеалан концепт образовања, питање је шта се стварно променило и јесу ли промене у образовању утицале на промену положаја ученика у настави или, још увек, у овом домену постоји несклад између савремене педагошке теорије и наставне праксе. Развој науке, технике и технологије донео је, и у будућности ће доносити, брзе промене у образовању, али ипак, наука, 
техника и технологија неће моћи да васпитавају личности. Зато, у тражењу повољних услова који могу да буду у функцији поспешивања и пуног остваривања субјекатске позиције ученика у савременој настави треба поћи од успостављања другачијих, хуманијих, равноправнијих и, пре свега, непосреднијих односа између ученика и наставника. Стварање позитивне педагошке климе која омогућава партнерски однос између ученика и наставника, темељно је питање савремене школе, од чијег решавања зависи и остваривање главног циља: ученик активни и истински субјект савремене наставе.

КључнЕ РЕчи: настава; ученик; наставник; положај ученика; улога ученика.

Овај чланак је објављен и дистрибуира се под лиценцом Creative Commons Ауторство-Некомерцијално Међународна 4.0 (СC BY-NC 4.0 |

https://creativecommons.org/licenses/by-nc/4.0/).

This paper is published and distributed under the terms and conditions of the Creative Commons Attribution-NonCommercial International 4.0 licence (CC BY-NC 4.0 | https://creativecommons.org/licenses/by-nc/4.0/). 